\title{
PERILAKU PEMILIHAN MAKANAN TINGGI NATRIUM BERPENGARUH TERHADAP ASUPAN NATRIUM PENDERITA HIPERTENSI DI KOTA SEMARANG
}

\author{
Heni Hendriyani, Estuasih Dyah Pertiwi, Sri Noor Mintarsih \\ Jurusan Gizi Poltekkes Kemenkes Semarang \\ heni_sahid@yahoo.com
}

\begin{abstract}
ABSTRAK
World Health Organization (WHO) menyatakan satu dari tiga orang dewasa di seluruh dunia memiliki tekanan darah tinggi dan proporsinya meningkat seiring meningkatnya usia. Di Indonesia, Hasil Riset Kesehatan Dasar (Riskesdas) Tahun 2007 menunjukkan prevalensi hipertensi secara nasional mencapai 31,7 persen dan di Propinsi Jawa Tengah prevalensinya mencapai 37 persen. Penelitian ini bertujuan untuk mengetahui perilaku pemilihan makanan tinggi natrium yang meliputi pengetahuan, sikap dan praktek serta hubungannya dengan asupan natrium. Desain penelitian cross-sectional. Sejumlah 60 wanita dewasa usia 36 sampai 76 tahun menjadi responden dengan kriteria inklusi menderita hipertensi kurang dari 3 tahun dan tidak sedang menjalani program diet. Pengetahuan dan sikap pemilihan makanan tinggi natrium dikumpulkan dengan wawancara dilengkapi kuesioner sedangkan praktek dan asupan natrium dikumpulkan dengan semi quantitative food frequency questionnaire. Analisis data dengan chi square dan korelasi pearson. Asupan natrium responden rata-rata sebesar $3604,10 \mathrm{mg}$. Sejumlah 96,7 persen responden asupan natriumnya di atas anjuran $(<2400 \mathrm{mg}$ ). Proporsi responden dengan pengetahuan kurang, sikap kurang dan konsumsi makanan tinggi natriumnya sering memiliki asupan natriumnya tinggi yaitu masing-masing 54,5 persen, 63,6 persen dan 84,8 persen. Ada hubungan negatif yang signifikan antara pengetahuan dan sikap dengan asupan natrium dengan masing-masing nilai $r=$ 0,$508 ; p=0,000 ; r=-0,342 ; p=0,008$ dan ada hubungan positif signifikan antara praktek dengan asupan natrium $(r=0,782 ; p=0,000)$. Hasil penelitian ini menunjukkan responden yang merupakan penderita hipertensi sering mengkonsumsi makanan sumber natrium tinggi. Pemberian pemahaman mengenai risiko asupan natrium yang tinggi terhadap kesehatan kepada masyarakat akan sangat bermanfaat.
\end{abstract}

Kata kunci: perilaku makan, asupan natrium, hipertensi

\section{ABSTRACT \\ FOOD SELECTION BEHAVIOR RELATED TO NATRIUM INTAKE AMONG HYPERTENSION OUTPATIENTS IN SEMARANG}

High natrium intake is one of hypertension risk factors. Basic health research data in 2007 showed that in Indonesia, hypertension prevalence in community reached 31.7 per cent and in Central Java the prevalence was 37 per cent. The objective of the study was to find out high natrium food behavior which included knowledge, attitude and practice as well as to analyze their relationship with natrium intake. The study used cross sectional design. There were 60 adult women selected as respondents aged 36 to 76 years with inclusion criteria as being hypertension less than 3 years and was not in a diet program. Knowledge and attitude were collected by interviewing them using questionnaire. Practices and natrium intake data were collected using semi quantitative food frequency questionnaire. The results showed that mean of natrium intake was $3604,10 \mathrm{mg}$. Majority $(96,7 \%)$ of respondents had natrium intake above recommendation ( $<2400 \mathrm{mg}$ ). Respondents with poor knowledge and attitude as well as high consumption of natrium rich food had high intake of natrium 54,5 per cent, 63,6 per cent dan 84,8 per cent respectively. There were negative significant correlation between knowledge $(r=-0,508 ; p=0,000)$ and attitude $(r=-0,342$; $p=0,008$ ) with natrium intake. There was a positive significant correlation between practice and natrium intake $(r=0,782 ; p=0,000)$. High consumption of natrium rich food was considered prevalent in the community. It was essential to educate people the negative effect of high natrium consumption.

Keywords: dietary behavior, natrium intake, hypertension

\section{PENDAHULUAN}

A supan natrium yang tinggi merupakan salah satu penyebab meningkatnya tekanan darah yang dapat mengarah pada risiko kematian di seluruh dunia. Meningkatnya tekanan darah menjadi pemicu kematian dini dan konsumsi garam yang berlebihan meningkatkan tekanan darah pada bayi dan anak-anak, orang dengan tekanan 
darah normal dan orang dewasa yang memiliki hipertensi. Asupan garam pada masyarakat telah meningkat hingga 10 kali lipat dalam beberapa ratus tahun terakhir ${ }^{1}$. Tingginya asupan garam (natrium) yang tinggi merupakan pencetus dari kanker usus, osteoporosis, keparahan asma, batu ginjal dan obesitas².

World Health Organization (WHO) menyatakan satu dari tiga orang dewasa di seluruh dunia memiliki tekanan darah tinggi dan proporsinya meningkat seiring meningkatnya usia $^{3}$. Di Indonesia, Hasil Riset Kesehatan Dasar (Riskesdas) tahun 2007 menunjukkan prevalensi hipertensi secara nasional mencapai 31,7 persen dan di Propinsi Jawa Tengah prevalensinya mencapai 37 persen ${ }^{4}$.

Tekanan darah tinggi bisa dicegah dan diatasi pada hipertensi primer ${ }^{2}$. Kemungkinan terjadinya hipertensi dan semua penyakit yang dipicunya dapat diminimalisir dengan melakukan pola hidup yang sehat seperti pola makan yang sehat seimbang, mengkonsumsi sayur dan buah, mengurangi lemak jenuh dan mengurangi asupan garam (natrium) hingga 5 gram per hari ${ }^{3}$. Jumlah garam/natrium merupakan faktor determinan penting level tekanan darah dan risiko hipertensi dan pengurangan asupan garam/natrium pada individu merupakan intervensi yang tepat dalam menurunkan tekanan darah, meningkatkan efisiensi terapi obat dan menurunkan risiko global dari penyakit cardiovascular ${ }^{5}$.

Seiring dengan kemajuan teknologi, makanan olahan yang diproduksi di industri sangat mudah dijumpai akhir-akhir ini. Pilihan makanan olahan di pasaran sudah sangat beragam. Makanan olahan cenderung mengandung natrium yang cukup tinggi. Pemahaman masyarakat mengenai pemilihan makanan yang tinggi natrium akan sangat bermanfaat untuk membantu mereka memilih makanan yang sehat dan mengandung natrium dalam jumlah yang cukup sesuai kebutuhan. Penelitian ini bertujuan untuk mengetahui perilaku pemilihan makanan tinggi natrium yang meliputi pengetahuan, sikap dan praktek serta hubungannya dengan asupan natrium.

\section{METODE PENELITIAN}

Desain penelitian ini adalah survei potong lintang (cross sectional). Penelitian dilakukan di unit rawat jalan RSUD Kota Semarang. Data dikumpulkan pada bulan September - Oktober 2013. Populasi penelitian ini adalah penderita wanita hipertensi yang datang untuk rawat jalan di RSUD Kota Semarang. Sampel penelitian adalah penderita hipertensi yang datang untuk rawat jalan di RSUD Kota Semarang dan memenuhi kriteria inklusi penelitian. Sampel diambil dengan dengan cara purposive sampling. Kriteria inklusi sampel adalah wanita dewasa, menderita hipertensi dalam kurun waktu kurang dari 3 tahun, tidak sedang menjalani diet karena komplikasi penyakit lain dan bersedia mengikuti penelitian. Dari hasil perhitungan tersebut didapatkan jumlah sampel minimal sebanyak 57 orang berusia antara 36 sampai 76 Tahun 6 .

Data yang dikumpulkan meliputi karakteristik responden (umur, jenis kelamin, pendidikan, pekerjaan, pendapatan, etnis). Data ini dikumpulkan dengan wawancara menggunakan kuesioner. Data Indeks Massa Tubuh (IMT) diperoleh dengan mengukur tinggi badan dan menimbang berat badan sedangkan pengetahuan dan sikap dikumpulkan dengan wawancara dengan kuesioner. Kategori IMT merujuk dari rujukan Kementerian Kesehatan RI Tahun 2003 yaitu kurus (IMT < 18,5), normal (IMT 18,5 - 25), gemuk (IMT >25). Sejumlah 6 pertanyaan pengetahuan diisi dengan memilih jawaban sesuai pengetahuan responden dan 18 pertanyaan dengan memilih makanan mana yang lebih tinggi kandungan natriumnya. Sedangkan lima belas pernyataan sikap diisi dengan mengisi pilihan jawaban sikap dengan skala Likert yang meliputi sangat setuju, setuju, tidak setuju dan sangat tidak setuju.

Praktek pemilihan makanan tinggi natrium dikumpulkan menggunakan semi kuantitatif food frequency questionnaire kemudian melist makanan tinggi natrium yang dikonsumsi responden lebih dari satu kali sehari, sekali dalam sehari dan satu kali dalam tiga hari. Asupan natrium dikumpulkan dengan wawancara menggunakan semi kuantitatif food frequency questionnaire yang dilengkapi dengan food model oleh Ahli Gizi yang telah dilatih7. Kuesioner untuk mengukur karakteristik, pengetahuan, sikap dan praktek pemilihan makanan tinggi natrium disusun oleh peneliti dan telah di-review serta diuji coba. Telah duji reliabilitasnya dengan nilai Cronbach alpha untuk pengetahuan $(0,65)$, sikap $(0,61)$ dan praktek $(0,8)$. Pengumpulan data dilakukan oleh 
Ahli Gizi yang telah dilatih didampingi peneliti dan petugas Poliklinik Penyakit Dalam RSUD Kota Semarang. Analisis univariat dilakukan untuk mendapatkan gambaran umum responden dan karakteristik variabel. Analisis bivariate dengan uji Korelasi Pearson. Untuk semua analisis statistik menggunakan $\alpha=0.05$.

\section{HASIL}

\section{Karakteristik Sampel}

Dari Tabel 1 terlihat bahwa umur rata-rata responden 54 tahun, umur termuda 36 tahun dan tertua 76 tahun. Hipertensi sudah mulai diderita oleh wanita berumur relatif muda (36 tahun). Tabel 2 menunjukkan indeks massa tubuh responden sebagian besar termasuk gemuk (IMT > 25) yaitu sejumlah 70 persen. Status gizi gemuk merupakan salah satu faktor risiko hipertensis,9. Dari Tabel 3 tampak bahwa sebagian besar responden memiliki riwayat keluarga hipertensi $(70 \%)$; berpendidikan tamat SLTP ke bawah (70\%); tidak bekerja $(68,3 \%)$ dan dalam status ekonomi rendah (pendapatan $<$ Rp 2 juta per bulan).

\section{Pengetahuan, Sikap dan Praktek Pemilihan Makanan Tinggi Natrium}

Sebagian besar responden (90\%) belum mengetahui nama zat gizi yang identik dengan sumber rasa asin yaitu natrium, sumber-sumber natrium $(95 \%)$ dan jumlah natrium yang dianjurkan dalam sehari (98,3\%). Natrium yang dianjurkan oleh WHO kurang dari $2400 \mathrm{mg}$ sehari ${ }^{7}$. Namun dari tabel 4 terlihat sebagian besar pertanyaan mengenai pemilihan makanan yang lebih banyak mengandung natrium dijawab dengan benar oleh sebagian besar responden.

Dari Tabel 5 diketahui bahwa sebagian besar responden tidak setuju jika penggunaan vetsin dan bumbu penyedap tidak dilakukan yaitu sebanyak $78,3 \%$ serta menghindari makanan yang ditambah dengan vetsin yaitu $71,7 \%$. Demikian pula dengan penggunaan bumbu instan, hampir setengah $(43,3 \%)$ dari responden menyatakan tidak setuju untuk tidak menggunakan bumbu instan dan jarang menambahkan kecap ketika makan (55\%).

Tabel 1

Distribusi Umur dan Indeks Massa Tubuh

\begin{tabular}{lcccc}
\hline Variabel & Rerata & Median & Min-Maks & SD \\
\hline Umur (Tahun) & 54,28 & 55,50 & $36,00-76,00$ & $\pm 10,04$ \\
IMT (kg/m2) & 26,27 & 25,91 & $14,80-54,11$ & $\pm 6,73$ \\
\hline IMT: (Indeks Massa Tubuh) & & &
\end{tabular}

Tabel 2

Distribusi kategori Indeks Massa Tubuh (IMT)

\begin{tabular}{lcc}
\hline Status IMT & Frekuensi & Persen \\
\hline Kurus & 5 & 8,3 \\
Normal & 13 & 21,7 \\
Gemuk & 42 & 70,0 \\
\hline Jumlah & 60 & 100,0 \\
\hline
\end{tabular}

IMT: (Indeks Massa Tubuh) 
Tabel 3

Distribusi Responden berdasarkan Riwayat Hipertensi, Pendidikan Terakhir, Status Pekerjaan dan Penghasilan Keluarga

\begin{tabular}{lcc}
\hline Variabel & Frekuensi & Persen \\
\hline Riwayat Hipertensi & 42 & \\
-Ya & 18 & 70,0 \\
-Tidak & 6 & 30,0 \\
\hline Pendidikan Terakhir & 12 & 10,0 \\
-Tidak pernah sekolah & 12 & 20,0 \\
-Tidak tamat SD & 13 & 20,0 \\
-Tamat SD/MI & 11 & 21,7 \\
-Tamat SLTP/MTS & 6 & 18,3 \\
-Tamat SLTA/MA & & 10,0 \\
-Tamat PT & 41 & \\
Status Pekerjaan & 7 & 68,3 \\
-Tidak kerja & 5 & 11,7 \\
-PNS/Pegawai & 4 & 8,3 \\
-Wiraswasta/Layan jasa/Dagang & 3 & 6,7 \\
-Petani/Nelayan & & 5,0 \\
-Buruh & 52 & 86,7 \\
Penghasilan Keluarga & 5 & 8,3 \\
-Rp <1.000.000-Rp 2.000.000 & 3 & 5,0 \\
-Rp 2.000.000 - Rp 3.000.000 & 60 & 100,0 \\
-Rp 3.000.000 - Rp.4.000.000 & & \\
\hline Jumlah & & \\
\hline
\end{tabular}

Tabel 4

Distribusi Pengetahuan Pemilihan Makanan Tinggi Natrium

\begin{tabular}{lcc}
\hline & \multicolumn{2}{c}{ Jawaban } \\
\cline { 2 - 3 } Pertanyaan & Benar & Salah \\
& $\mathbf{n}(\%)$ & $\mathbf{n}(\%)$ \\
\hline 1. Nama zat gizi yang menjadi sumber rasa asin & $5(8,3)$ & $55(91,7)$ \\
2. Nama lain natrium & $6(10,0)$ & $54(90,0)$ \\
3. Sumber rasa asin & $3(5,0)$ & $57(95,0)$ \\
4. Jumlah natrium yang diperlukan dalam tubuh & $1(1,7)$ & $59(98,3)$ \\
5. Jenis makanan yang mengandung natrium & $18(30,0)$ & $42(70,0)$ \\
6. Sumber informasi tentang natrium sumber & $15(25,0)$ & $45(75,0)$ \\
\hline Pemilihan bahan makanan yang lebih banyak mengandung natrium & \\
\hline 7. Beras vs Bihun & $47(78,3)$ & $13(21,7)$ \\
8. Havermout vs Biskuit & $45(75,0)$ & $15(25,0)$ \\
9. Kentang vs Kripik kentang & $58(96,7)$ & $2(3,3)$ \\
10. Makaroni vs Roti bakar & $30(50,0)$ & $30(50,0)$ \\
11. Ubi vs Roti Susu & $43(71,7)$ & $17(28,3)$ \\
12. Singkong vs Roti coklat & $45(75,0)$ & $15(25,0)$ \\
13. Ayam vs Corned Beef & $45(75,0)$ & $15(25,0)$ \\
14. Daging Sapi vs Ham & $42(70,0)$ & $18(30,0)$ \\
15. Ikan segar vs Ik. asin & $59(98,3)$ & $1(1,7)$ \\
16. Telur. Ayam vs Telur Asin & $59(98,3)$ & $1(1,7)$ \\
17. Kc. Kedele vs Kecap & $51(85,0)$ & $9(15,0)$ \\
18. Kc Tanah vs Keju Kc tanah & $51(85,0)$ & $9(15,0)$ \\
19. Nasi putih vs Nasi Uduk & $58(96,7)$ & $2(3,3)$ \\
20. Daging segar vs Sosis & $52(86,7)$ & $8(13,3)$ \\
21. Wingko babat vs Martabak & $48(80,0)$ & $12(20,0)$ \\
22. Daging segar vs Dendeng & $52(86,7)$ & $8(13,3)$ \\
23. Kopi vs bubuk coklat & $24(40,0)$ & $36(60,0)$ \\
24. Tomat vs Saus tomat & $57(95,0)$ & $3(5,0)$ \\
\hline
\end{tabular}


Tabel 5

Distribusi Sikap Pemilihan Makanan Tinggi Natrium

\begin{tabular}{lcccc}
\hline Pernyataan sikap & Sangat setuju & Setuju & Tidak setuju & \multicolumn{2}{c}{ Sangat tidak setuju } \\
\hline & $\mathrm{n}(\%)$ & $\mathrm{n}(\%)$ & $\mathrm{n}(\%)$ & $\mathrm{n}(\%)$ \\
\hline 1. Lebih memilih makanan segar daripada olahan & $4(6,7)$ & $52(86,6)$ & $4(6,7)$ & $0(0)$ \\
2. Tidak menggunakan vetsin atau bumbu penyedap & $1(1,7)$ & $11(18,3)$ & $47(78,3)$ & $1(1,7)$ \\
$\quad$ ketika masak & & & & $0(0)$ \\
3. Menghindari makanan yang ditambah dengan vetsin & $1(1,7)$ & $16(26,6)$ & $43(71,7)$ & $0(0)$ \\
4. Tidak menambahkan garam meja ketika makan & $2(3,3)$ & $30(50)$ & $28(46,7)$ & $0(0)$ \\
5. Memilih makanan yang direbus daripada digoreng & $1(1,7)$ & $39(65,0)$ & $20(33,3)$ & $0(0)$ \\
6. Menghindari penggunaan bumbu masakan instan & $1(1,7)$ & $33(55)$ & $26(43,3)$ & $0(0)$ \\
7. Memilih daging segar daripada daging olahan & $2(3,3)$ & $57(95,0)$ & $1(1,7)$ & $0(0)$ \\
8. Ketika menggoreng lebih memilih minyak goreng & $1(1,7)$ & $50(83,3)$ & $9(15,0)$ & $0(0)$ \\
$\quad$ daripada mentega/margarin & & & $35(58,3)$ & $0(0)$ \\
9. Memilih kerupuk mie daripada kerupuk udang & $0(0)$ & $25(41,7)$ & $17(28,3)$ & $0(0)$ \\
10. Memilih kentang goreng daripada keripik kentang & $2(3,3)$ & $41(68,3)$ & $11(18,3)$ & $0(0)$ \\
11. Memilih telur rebus daripada telur asin & $0(0)$ & $49(81,7 \%)$ & $33(55,0)$ & $0(0)$ \\
12. Jarang menambahkan kecap ketika makan & $1(1,7)$ & $26(43,3)$ & $6(10,0)$ & $1(1,7)$ \\
13. Memilih udang segar daripada udang kering & $2(3,3)$ & $52(86,7)$ & $12(20,0)$ & $1(1,7)$ \\
14. Memilih nasi putih daripada nasi uduk/nasi goreng & $0(0)$ & $47(78,3)$ & $2(3,3)$ & \\
15. Memilih sayur bening daripada sayur semur kecap & $1(1,7)$ & $56(93,3)$ & & \\
\hline
\end{tabular}

Tabel 6

Distribusi Praktek Pemilihan Makanan

\begin{tabular}{lcc}
\hline \multirow{2}{*}{ Praktek Konsumsi Makanan Tinggi Natrium (Lebih dari Satu } & \multicolumn{2}{c}{ Jawaban } \\
\cline { 2 - 3 } Kali Sehari/ Sekali dalam Sehari/Satu Kali dalam 3 Hari) & $\mathrm{n}(\%)$ & $\mathrm{T}(\%)$ \\
\hline 1. Bihun & $15(25,0)$ & $45(75.0)$ \\
2. Biskuit & $39(65,0)$ & $21(35,0)$ \\
3. Crackers & $21(35,0)$ & $39(65,0)$ \\
4. Roti bakar & $11(18,3)$ & $49(81,7)$ \\
5. Roti coklat & $24(40,0)$ & $36(60,0)$ \\
6. Roti susu & $30(50,0)$ & $30(50,0)$ \\
7. Ikan sarden & $5(8,3)$ & $55(91,7)$ \\
8. Kecap & $53(88,3)$ & $7(11,7)$ \\
9. Es krim & $4(6,7)$ & $56(93,3)$ \\
10. Susu kental manis & $34(56,7)$ & $26(43,3)$ \\
11. Margarin & $33(55,0)$ & $27(45,0)$ \\
12. Kaldu blok & $26(43,3)$ & $34(56,7)$ \\
13. Vetsin/MSG & $49(81,7)$ & $11(18,3)$ \\
14. Bumbu penyedap lainnya & $50(83,3)$ & $10(16,7)$ \\
15. Bakso & $28(46,7)$ & $32(53,3)$ \\
16. Mie & $44(73,3)$ & $16(26,7)$ \\
17. Nasi rames & $39(65,0)$ & $21(35,0)$ \\
18. Kerupuk kemplang & $42(70,0)$ & $18(30,0)$ \\
19. Keripik kentang & $8(13,3)$ & $52(86,7)$ \\
20. Keripik singkong & $19(31,7)$ & $41(68,3)$ \\
21. Cap cai & $14(23,3)$ & $46(76,7)$ \\
22. Ikan teri & $38(63,3)$ & $22(36,7)$ \\
23. Ikan asin & $37(68,3)$ & $23(31,7)$ \\
24. Pempek & $14(23,3)$ & $46(76,7)$ \\
25. Telur asin & $18(30,0)$ & $42(70,0)$ \\
\hline
\end{tabular}


Tabel 7

Katagori Asupan Natrium berdasarkan Anjuran

\begin{tabular}{lcc}
\hline Asupan $(\mathrm{mg})$ & Frekuensi & Persen \\
\hline$<2400$ & 2 & 3,3 \\
$\geq 2400$ & 58 & 96,7 \\
\hline Jumlah & 60 & 100,0 \\
\hline
\end{tabular}

Tabel 8

Korelasi antara Pengetahuan, Sikap dan Praktek Pemilihan Makanan Tinggi Natrium dengan Asupan Natrium

\begin{tabular}{lccccc}
\hline Variabel & Rerata & Min-maks & SD & $r$ & $p$ \\
\hline Skor pengetahuan & 18,70 & $13-25$ & 2,75 & $-0,508$ & 0,000 \\
Skor sikap & 40,32 & $36-47$ & 2,52 & -0.342 & 0,008 \\
Skor praktek & 33,80 & $13-46$ & 7,64 & 0,782 & 0,000 \\
\hline
\end{tabular}

Table 9

Multivariate Analisis Hubungan Pengetahuan, Sikap dan Praktek dengan Asupan Natrium

\begin{tabular}{lccccc}
\hline & \multicolumn{3}{c}{ Adjusted $95 \% \mathrm{Cl}$} \\
\cline { 2 - 6 } Variabel & $\mathrm{B}$ & S.E. & $\mathrm{p}$ & Minimum & Maximum \\
\hline Pengetahuan & $-67,30$ & 22,264 & 0,004 & $-111,907$ & $-22,706$ \\
Sikap & $-36,53$ & 23,475 & 0,125 & $-83,562$ & $-10,489$ \\
Praktek & 65,08 & 8,238 & 0,000 & 48,584 & 81,588 \\
\hline
\end{tabular}

\section{Deskripsi asupan natrium}

Rata-rata asupan natrium responden penelitian ini adalah $3604.10 \pm 755.46 \mathrm{mg}$. Dengan nilai maksimum $5794 \mathrm{mg}$. Data asupan natrium diperoleh dari semi quantitative food frequency questionnaire dan juga ditanyakan tentang penggunaan garam meja, garam saat memasak, konsumsi makanan olahan, makanan jadi serta penggunaan MSG dengan food model. Data asupan natrium dianalisis dengan menggunakan program nutrisurvey untuk makanan dan dilakukan perhitungan terpisah (manual) untuk garam, vetsin/MSG.

Tabel 7 menunjukkan hampir seluruh responden (96,7\%) asupan natriumnya melebuhi anjuran. Tekanan darah tinggi bisa dicegah dan diatasi pada hipertensi primer. Kemungkinan terjadinya hipertensi dan semua penyakit yang dipicunya dapat dikurangi dengan melakukan pola hidup yang sehat seperti pola makan yang sehat dan seimbang, mengonsumsi sayur-sayuran dan buah-buahan, mengurangi konsumsi lemak jenuh dan mengurangi asupan garam (natrium) hingga 5 gram per hari atau setara dengan $2400 \mathrm{mg}$ natrium. $^{3}$

Korelasi antara pengetahuan, sikap dan praktek pemilihan makanan tinggi natrium dengan asupan natrium

Dari Tabel 8 terlihat nilai korelasi skor pengetahuan $(r)=-0,508$ dan nilai $p=0,000$, sehingga dapat disimpulkan ada hubungan antara skor pengetahuan dan jumlah asupan natrium. Nilai negatif pada $r$, menunjukkan adanya hubungan negatif. Semakin tinggi skor pengetahuan memiliki kecenderungan semakin rendah jumlah asupan natrium.

Sedangkan nilai korelasi sikap $(r)=-0,342$ dan nilai $p=0,008$, sehingga dapat disimpulkan ada hubungan antara skor sikap dan jumlah asupan natrium. Nilai negatif pada $r$, menunjukkan adanya hubungan negatif. Semakin tinggi skor sikap memiliki kecenderungan semakin rendah jumlah asupan natrium.

Skor praktek memiliki nilai korelasi $(r)=$ 0,782 dan nilai $p=0,000$, sehingga dapat disimpulkan ada hubungan antara skor praktek 
dan jumlah asupan natrium. Nilai positif pada $r$, menunjukkan adanya hubungan positif. Semakin tinggi skor praktek konsumsi makanan yang mengandung natrium memiliki kecenderungan semakin tinggi pula jumlah asupan natrium. Hasil analisis multivariate menunjukkan pengetahuan dan praktek merupakan prediktor yang signifikan untuk asupan natrium seperti terlihat pada Tabel 9.

\section{Hubungan antara Pengetahuan dan Asupan Natrium}

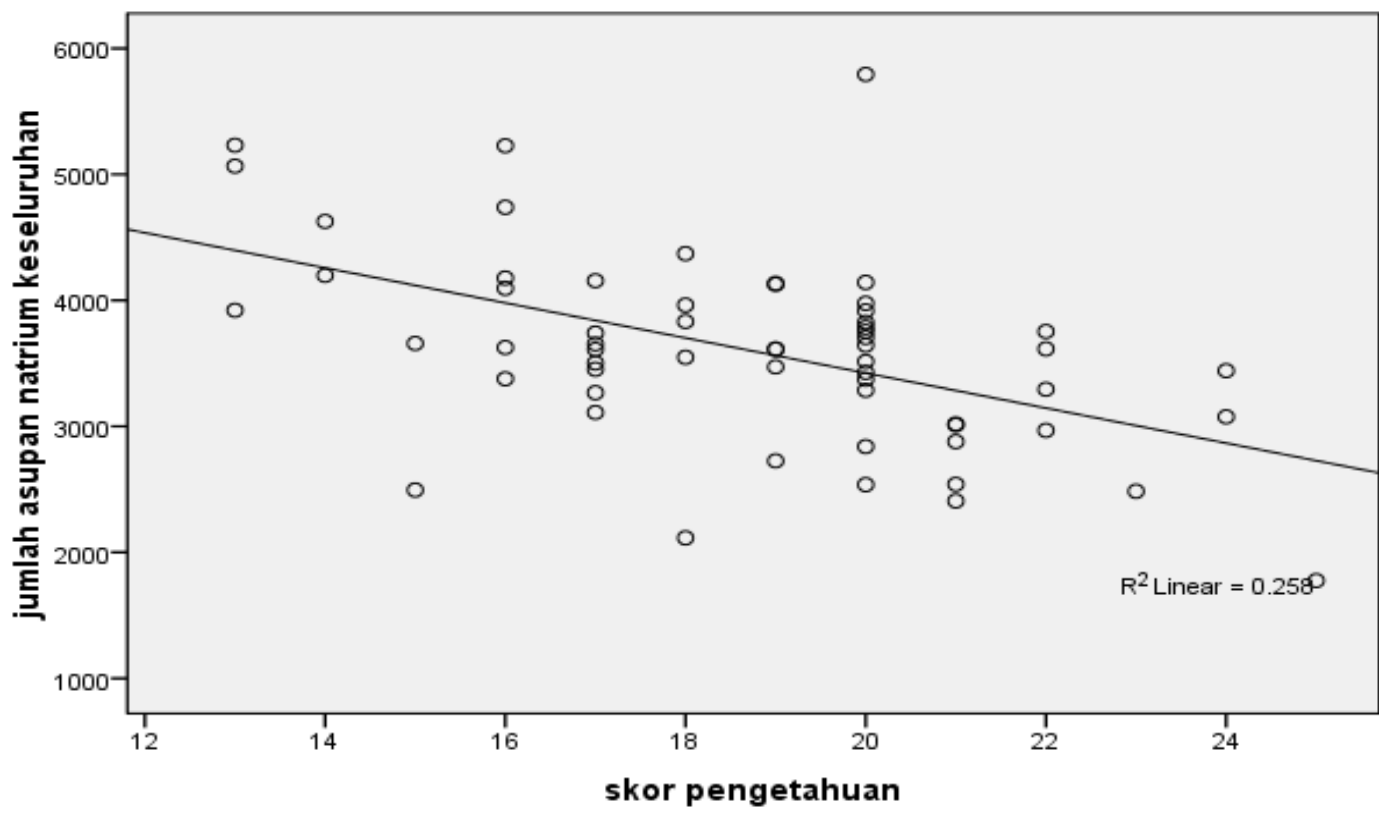

Gambar 3. Sebaran hubungan pengetahuan dengan asupan natrium

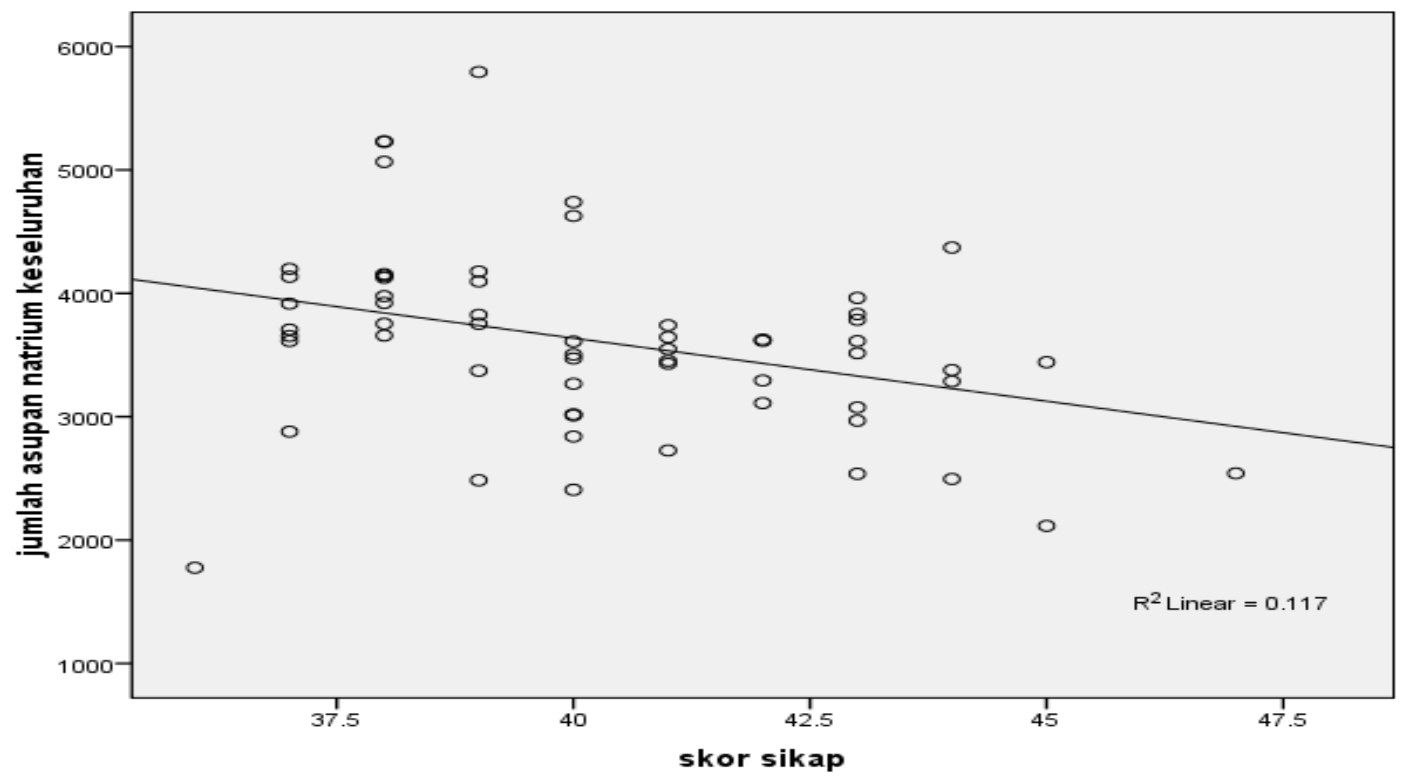

Gambar 4

Sebaran hubungan sikap dengan asupan natrium 


\section{Hubungan antara Praktek dan Asupan Natrium}

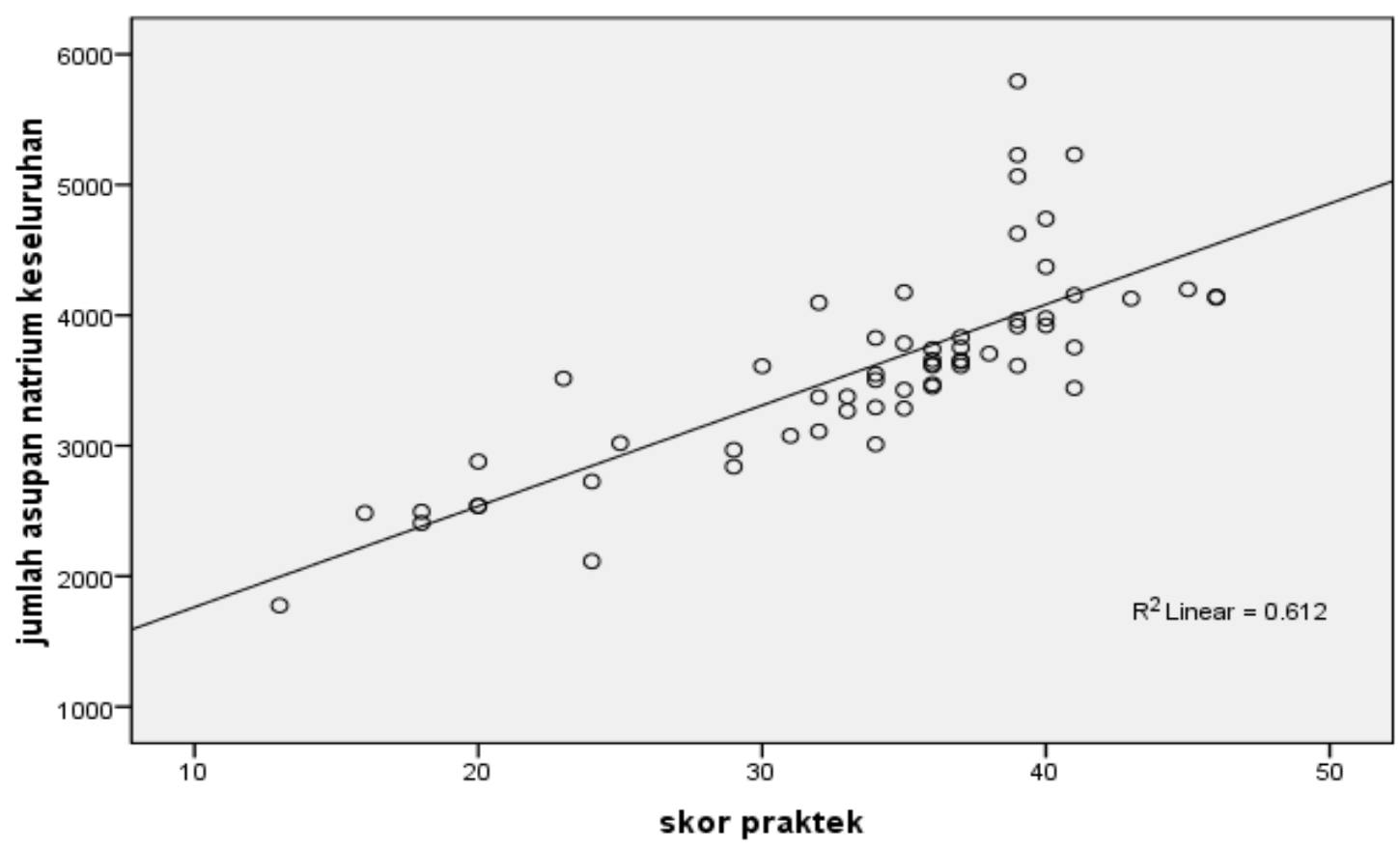

Gambar 5

Sebaran Hubungan Praktek Pemilihan Makanan dengan Asupan Natrium

\section{BAHASAN}

Tekanan darah tinggi merupakan faktor risiko utama kematian di seluruh dunia yaitu sekitar 51 persen penyebab stroke dan 45 persen penyakit jantung iskemik ${ }^{5}$.

Penyusunan kuesioner dilakukan berdasarkan daftar komposisi bahan makanan Indonesia sehingga dipilih bahan makanan yang mengandung natrium tinggi ${ }^{10}$. Kuesioner yang menanyakan informasi spesifik mengenai pengetahuan, sikap dan praktek masyarakat terhadap makanan tinggi natrium sering digunakan ${ }^{5}$. Data praktek pemilihan makanan tinggi natrium dan asupan natrium dikumpulkan dengan menggunakan semi quantitative food frequency questionnaire yang juga menanyakan penggunaan garam dan bumbu penyedap.

Hasil penelitian ini menunjukkan umur ratarata responden 55 tahun dan IMT/BMI 26 dan $70 \%$ gemuk. Hasil ini sejalan dengan hasil penelitian Peer et al (2013) di Afrika Selatan, dimana rata-rata umur responden di atas 50 tahun dan rata-rata BMI 26 dengan status gizi hampir 70 persen gemuk ${ }^{8}$. Demikian pula ratarata asupan natrium mencapai $3,6 \mathrm{gr}$ dimana angka ini sesuai dengan penelitian oleh Dariush et al (2014) dimana rata-rata asupan natrium mencapai 3,9 gr berada jauh diatas angka yang direkomendasikan yaitu 2,4 gr sehari18

Sebagian besar responden menjawab salah pada pertanyaan mengenai nama zat gizi yang merupakan sumber rasa asin yaitu natrium. Demikian pula dengan sumber natrium pada makanan serta jumlah natrium yang dianjurkan dalam sehari. $\mathrm{Hal}$ ini mengindikasikan pengetahuan masyarakat mengenai natrium masih perlu ditingkatkan. Dalam memilih makanan yang lebih tinggi natrium masih ada responden yang menjawab salah terutama pada kopi dibandingkan bubuk coklat, susu dibandingkan es krim dan beberapa makanan olahan dibandingkan makanan segar. Pengetahuan yang kurang baik mengenai makanan yang tinggi natrium ini bisa berdampak pada perilaku mengkonsumsi makanan yang tinggi natrium. 
Hasil penelitian ini menunjukkan korelasi yang kuat antara pengetahuan dengan asupan natrium dengan $r=-0,508$ dan $p=0,000$, semakin tinggi skor pengetahuan responden memiliki kecenderungan semakin rendah jumlah asupan natriumnya. Perilaku (praktek) yang akan berdampak pada jumlah asupan gizi sangat dipengaruhi pengetahuan, seseorang akan melakukan suatu perilaku jika dia mengetahui manfaat dari perilaku tersebut 11,12 .

Dari beberapa pernyataan yang mengukur sikap diketahui bahwa sebagian besar responden tidak setuju jika penggunaan vetsin dan bumbu penyedap serta penambahan garam meja dikurangi maupun dihindari. Demikian pula dengan penggunaan bumbu instan, hampir setengan dari responden menyatakan tidak setuju untuk tidak menggunakan bumbu instan. Hasil penelitian ini menunjukkan sikap ini berkorelasi cukup kuat dengan asupan natrium, sikap yang tidak mendukung pengurangan natrium berdampak pada asupan natrium yang tinggi $(r=-0,342$ dan nilai $p=0,008)$. Namun sikap seseorang terhadap suatu tindakan belum tentu dilaksanakan karena memerlukan faktor pendukung atau suatu kondisi yang memungkinkan ${ }^{11,12}$.

Terdapat hubungan yang sangat kuat antara praktek pemilihan makanan tinggi natrium dengan asupan natrium dengan nilai $r=0,782$ dan $p=0,000$. Semakin tinggi skor praktek konsumsi makanan yang mengandung natrium memiliki kecenderungan semakin tinggi pula jumlah asupan natrium. Dari kuesioner frekuensi makanan semi kuantitatif diketahui bahwa sebagian besar responden mengkonsumsi makanan sumber natrium tinggi satu kali atau lebih dalam satu hari yaitu kecap, margarin, MSG, bumbu penyedap, mie kemasan, nasi rames, kerupuk kemplang, ikan teri dan ikan asin. Hal ini membuktikan bahwa pola makan responden yang menderita hipertensi ini sering mengkonsumsi makanan sumber natrium tinggi. Hal ini sejalan dengan yang dikemukakan oleh Dickinson \& Havans (2007) dan Campbell et al (2011) yaitu sebagian besar natrium yang dikonsumsi masyarakat berasal dari makanan olahan, makanan restauran dan penambahan sumber natrium pada saat memasak ${ }^{1,13}$. Chen et al (2013) menyatakan bahwa pengurangan penggunaan garam akan sangat berdampak baik bagi penanggulangan hipertensi pada negara-negara dimana penggunaan garam banyak dilakukan pada saat memasak di rumah ${ }^{14}$. Sementara itu pengurangan intake garam di masyarakat yang salah satunya lewat jumlah garam yang ditambahkan pada makanan oleh industri makanan olahan akan menurunkan tekanan darah dan kematian akibat penyakit jantung di masyarakat seperti yang telah dilakukan di Inggris dan Finlandia ${ }^{19}$.

Hasil penelitian ini menunjukkan pengetahuan, sikap dan praktek pemilihan makanan tinggi natrium berhubungan dengan banyaknya asupan natrium. Hasil penelitian Shao et al, 2013; Chen et al, 2013 menunjukkan program kesehatan yang berkaitan dengan intervensi pengetahuan, sikap dan praktek pengurangan konsumsi garam ataupun makanan yang tinggi natrium berdampak pada pengurangan tekanan darah ${ }^{15,16}$.

\section{SIMPULAN DAN SARAN}

\section{Simpulan}

Pengetahuan, sikap dan praktek pemilihan makanan tinggi natrium berhubungan bermakna dengan asupan natrium.

\section{Saran}

Program komunikasi, informasi dan edukasi kepada masyarakat mengenai pola makan sehat terutama pemilihan makanan yang tidak mengandung natrium tinggi serta dampak pola makan yang tidak seimbang perlu terus ditingkatkan.

\section{RUJUKAN}

1. Campbell NRC, Neal BC and MacGregor GA. Interested in developing a national programme to reduce dietary salt. Journal of Human Hypertension 2011; 25: 705-710.

2. He FJ, MacGregor GA, A comprehensive review on salt and health and current experience of worlwide salt reduction programmes. J Hum Hypertension 2009; 23 (6):363-384.

3. World Health Organization Western Pacific Region. High blood pressure: the silent killer stay healthy: check your blood pressure. Geneva: WHO, 2013.

4. Departemen Kesehatan RI. Riset.Kesehatan Dasar 2007. Jakarta: 
Badan Penelitian dan Pengembangan Kesehatan, 2008

5. World Health Organization. Strategies to monitor and evaluate population sodium consumption and sources of sodium in the diet. Report of a joint technical meeting convened by $\mathrm{WHO}$ and the goverment of Canada. Switzerland: WHO, 2011.

6. Lemeshow S, Hosmer DW, Klar J, Lwanga SK. Adequacy of sample size in health studies. Geneva, World Health Organization, 1990.

7. Gibson, RS. Principle of Nutrition Assessment. 3rd edition. New York: Oxford University Press, 2008.

8. Peer N, Steyn K, Lombard C, Gwebushe N, Levitt N.. A high burden of hypertension in the urban black population of cape town: the cardiovascular risk in black south africans (CRIBSA) study. PloS ONE 2013, 8 (11): 78567- 78574.

9. Graudal NA, Hubeck-Graudal, Jurgens G. Effects of low-sodium diet vs. High-sodium diet on blood pressure, renin, aldosteron, catecholamines, cholesterol and triglyceride (Cochrane Review). American Journal of Hypertension 2012; 25 (1): 1-15.

10. PERSAGI. Daftar Komposisi Bahan Makanan. Jakarta: Persatuan Ahli Gizi Indonesia, 2011.

11. Notoatmodjo S. Promosi kesehatan dan ilmu perilaku. Jakarta: Rineka Cipta, 2007.

12. Notoatmodjo S. Konsep perilaku kesehatan. Dalam Promosi Kesehatan teori dan aplikasi. Editor Soekidjo Notoatmodjo. Jakarta: Rineka Cipta, 2005.
13. Dickinson B and Havas S. Reducing the population burden of cardiovascular disease by reducing sodium intake. Arch Intern Med 2007; 167(14):1460-1468.

14. Chen J, Tian Y, Liao Y, Yang S, Li Z, He C et al. Salt restriction-spoon improved the salt intake among residents in China. PloS ONE 2013; 8(11): e78963.

15. Shao JH, Chang AM, Edwars H, Shyu Yl, Chen SH. A randomized controlled trial of self-management programme improves health-related outcomes of older people with hearth failure. Journal of Advanced Nursing. 2013;69(11):2458-2469.

16. Taylor RS, Ashton KE, Moxham T, Hooper $L$ and Ebrahim S. Reduced dietary salt for the prevention of cardiovascular diesease: A meta analysis of randomized controlled trials. American Journal of Hypertension 2011;26 (8): 843-853.

17. PERSAGI. Penuntun Diet. Jakarta: Persatuan Ahli Gizi Indonesia, 2008.

18. Mozaffarian D, Fahimi S, Singh GM, Micha R, Khatibzadeh S, Engell RE et al. Global sodium consumption and death from cardiovascular causes. The New England Journal of Medicine 2014; August (371): 624-634.

19. He FJ and MacGregor GA. Salt intake, sugar sweetened soft drink consumption and blood pressure. The American Journal of Cardiology. 2014. http://dx.doi/10.1016/j.amjcard.2014.05.004 Available from www.ajconline.org. 